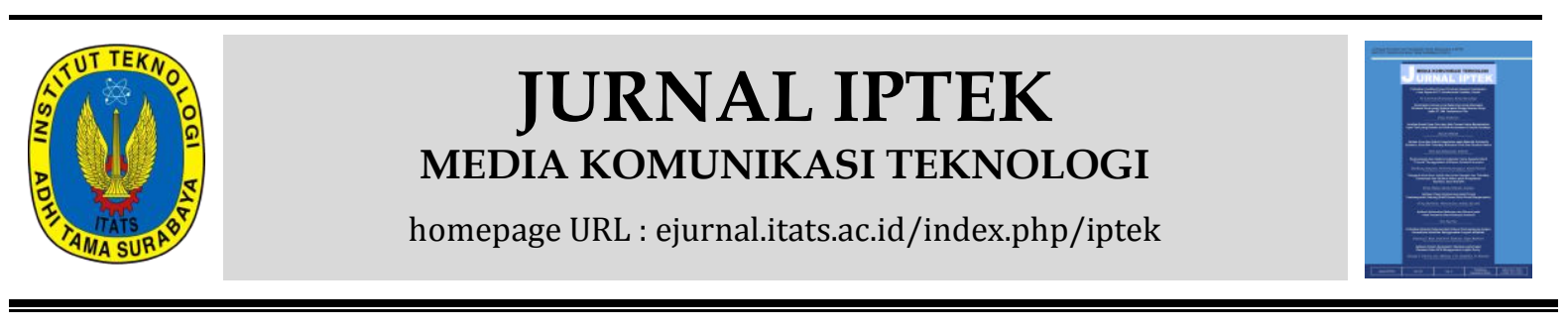

\title{
Studi Experimental Energi Bangkitan Pembangkit Listrik Tenaga Gelombang Laut Model Pelampung
}

Miftahul Ulum

Jurusan Teknik Mesin, Fakultas Teknologi Industri, Institut Teknologi Adhi Tama Surabaya

\begin{tabular}{l}
\hline INFORMASI ARTIKEL \\
\hline Jurnal IPTEK - Volume 22 \\
Nomer 1, Mei 2018 \\
ISSN:1411-7010 \\
e-ISSN:2477-507X \\
Halaman: \\
29-36 \\
DOI: \\
https://dx.doi.org/10.31284 \\
lj.iptek.2018.v22i1.231 \\
EMAIL
\end{tabular}

ulum@itats.ac.id

\section{RIWAYAT ARTIKEL}

Tanggal diterima :

11 April 2018

Tanggal diterbit :

31 Mei 2018

\section{PENERBIT}

LPPM- Institut Teknologi

Adhi Tama Surabaya

Jurnal IPTEK by LPPM-

ITATS is licensed under a

Creative Commons

Attribution-NonCommercial-

ShareAlike 4.0 International

License.

\begin{abstract}
Electrical energy needs keep growing as technology and information advances, it is necessary for the existence of renewable energy as a source of electrical energy in the future. One of them is sea wave energy. In previous studies, it has been discussed about cylindrical buoy type sea wave power plant with dimensions of length variation of the swing arm and the length of the buoy to the energy generated. Therefore this research will discuss about the influence of different inertia due to the ballast mass-base swing arm distance variation and the generator wire diameter variation, on the laboratory scaled sea wave power generator, to the generated electrical energy. The method used is experimental method with laboratory scale. Experiment has performed by variations are the ballast mass - base swing arm distance, $7 \mathrm{~cm}, 15 \mathrm{~cm}$ and $23 \mathrm{~cm}$, and the generator wire diameter, $0.2 \mathrm{~mm}, 0.3 \mathrm{~mm}$ and $0.4 \mathrm{~mm}$. The ballast mass - base swing arm distance does not give the significant effect. Whereas the greater generator wire diameter gives the higher generated power. The greatest occurs on the $0.4 \mathrm{~mm}$ wire diameter with value $0.02438 \mathrm{~W}$ and the system has $2.7 \%$ of efficiency.
\end{abstract}

Keywords: wire diameter; DC generator; ballast mass; cylindrical buoy; sea wave power generator.

\section{ABSTRAK}

Kebutuhan energi listrik kian berkembang seiring dengan kemajuan teknologi dan informasi, oleh karena itu perlu adanya energi terbarukan sebagai sumber energi listrik dimasa depan. Salah satunya adalah energi gelombang laut. Pada penelitian terdahulu, telah dibahas tentang pembangkit listrik tenaga gelombang laut tipe pelampung silinder dengan variasi dimensi panjang lengan ayun dan panjang pelampung terhadap energi yang dihasilkan. Oleh karena itu pada penelitian ini akan membahas tentang pengaruh jarak masa pemberat yang ada pada lengan ayun serta variasi diameter kawat yang digunakan generator, pada model pembangkit listrik tenaga gelombang laut dengan skala laboratorium untuk menghasilkan energi listrik. Metode yang digunakan adalah metode eksperimen dengan skala laboratorium. Eksperimen dilakukan dengan variasi jarak masa pemberat pada lengan ayun, dengan jarak $7 \mathrm{~cm}, 15 \mathrm{~cm}$, dan $23 \mathrm{~cm}$, dan variasi diameter kawat pada generator $0.2 \mathrm{~mm}, 0.3 \mathrm{~mm}, 0.4 \mathrm{~mm}$. Pada variasi jarak masa pemberat pada lengan ayun didapat hasil yang tidak terlalu berbeda secara signifikan. Sedangkan pada variasi diameter kawat semakin besar diameter maka daya yang dihasilkan lebih besar. Hasil tertinggi terjadi pada diameter kawat $0.4 \mathrm{~mm}$ dengan nilai $0.02438 \mathrm{~W}$ dan efisiensi sistem yang didapat $2.7 \%$.

Kata kunci: diameter kawat; generator DC; masa pemberat; pelampung silinder; PLTGL.

\section{PENDAHULUAN}

Wave Energy Converter (WEC) sebagai salah satu teknologi penghasil energi listrik dunia sudah banyak digunakan di negara-negara maju untuk memenuhi kebutuhan energi terbarukan dimasa mendatang [1]. Converter energi gelombang laut yang sudah banyak di gunakan dan 
dikembangkan adalah pemanen energi permanent magnet linier generator [2], dengan mekanisme naik turun seiring dengan datangnya gelombang yang melewati pelampung. Selain itu beberapa teknologi pemanen energi yang dikembang lainnya adalah Oscillating Water Column [3]-[4], dengan memanfaatkan sea water level atau energi potensial pada gelombang laut dan ruang kedap udara untuk menggerakkan turbin, serta masih banyak peralatan lainnya [5]. Selain daripada mekanisme peralatan, komponen terpenting lainnya yang terdapat pada peralatan pemanen energi adalah generator. Sebagai pengubah energi kinetik maupun potensial ke dalam energi listrik generator sudah banyak dikembangkan seperti halnya generator jenis linier maupun rotary [6]-[7][8]. Model pembangkit listrik tenaga gelombang laut pada penelitian ini sebelumnya sudah pernah diteliti oleh M. ulum dengan model perencanaan simulasi menggunakan software numerik dengan output dalam RMS volt [9].

Pada penelitian sebelumnya belum pernah dilakukan pembuatan alat (prototype) mekanisme PLTGL dengan menggunakan pelampung silinder skala laboratorium, dan belum pernah dilakukan eksperimen. Pada penelitian ini mekanisme pembangkit listrik dengan memanfaatkan gelombang laut tipe pelampung silinder dibuat dan di uji coba pada skala laboratorium. Beberapa alat yang dibutuhkan sebagai pendukung adanya gelombang air laut maka sistem menggunakan kolam dengan gelombang buatan [10]. Variasi yang digunakan pada model mekanisme pembangkit listrik tenaga gelombang laut dibuat sesuai dengan model simulasi penelitian sebelumnya, serta juga parameter - parameter yang digunakan. Yaitu penambahan masa pada lengan ayun dengan variasi jarak $7 \mathrm{~cm}, 15 \mathrm{~cm}$, dan $23 \mathrm{~cm}$, serta variasi diameter kawat menggunakan bahan tembaga dengan diameter $0.2 \mathrm{~mm}, 0.3 \mathrm{~mm}$, dan $0.4 \mathrm{~mm}$. Tujuan dari penelitian ini adalah mendapatkan hasil dari mekanisme pembangkit listrik tenaga gelombang laut yang sesuai dengan model simulasi sebelumnya. Output yang dihasilkan adalah dalam bentuk watt.

\section{TINJAUAN PUSTAKA}

Sebelumnya sudah pernah dibahas mengenai mekanisme pembangkit listrik menggunakan gelombang laut, yaitu pada penelitian [9] dengan cara simulasi model menggunakan software numeric. Alur penelitian yang digunakan yaitu dengan membuat model mekanisme seperti yang ditunjukkan pada Gambar 1.

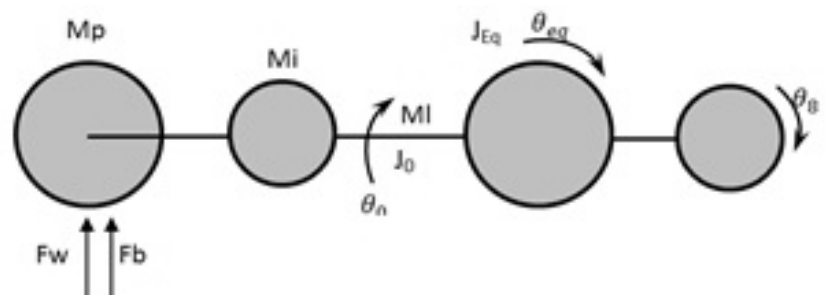

Gambar 1. Model Mekanisme Sistem [9]

Model mekanisme dari sistem akan dirubah kedalam persamaan numerik, dan selanjutnya di simulasikan menggunakan program numerik. Diagram alir penelitian sebelumnya di tampilkan pada Gambar 2. 


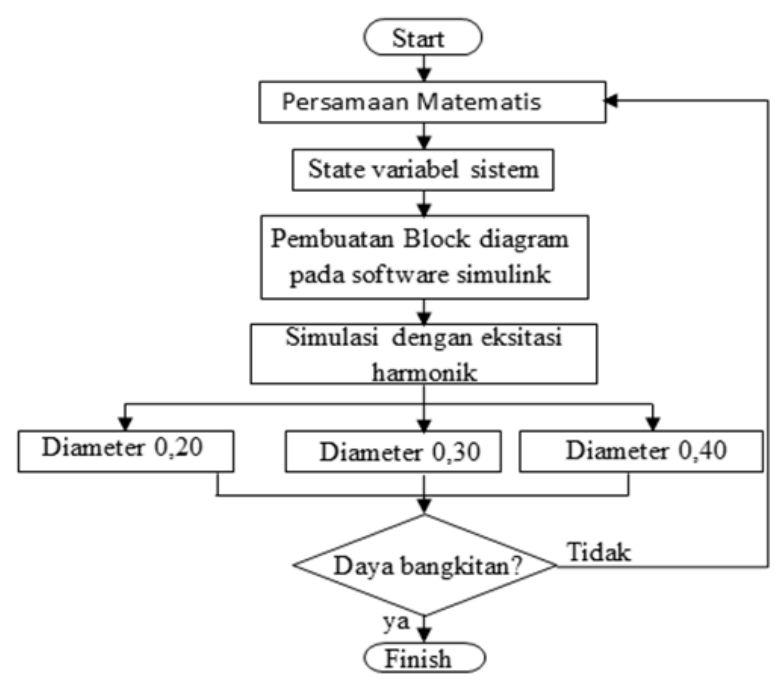

Gambar 2. Diagram Alir Penelitian Sebelumnya

Hasil dari penelitian sebelumnya berupa daya dalam (volt). Yaitu pada variasi diameter kawat generator $0.2,0.3$ dan $0.4 \mathrm{~mm}$ sebesar $0.02735 \mathrm{~V}, 0.03443 \mathrm{~V}$, dan $0.05027 \mathrm{~V}$.

\section{METODE}

Metode yang digunakan pada penelitian ini adalah metode eksperimen pada skala laboratorium. Model pembangkit listrik tenaga gelombang laut tipe pelampung silinder di desain dengan model mekanisme yang memiliki 3 bagian utama pada sistem kesatuan yaitu, bagian pertama pada pelampung jenis silinder dengan menggunakan lengan ayun dan variasi jarak pemberat, bagian kedua adalah roda gigi lurus yang memiliki perbandingan rasio 1:4 dengan menggunakan bantalan satu arah pada roda gigi pertama dan kedua, bagian ketiga ialah generator DC. Variasi diameter kawat pada generator terletak pada bagian rotor. Dalam melakukan pengujian mekanisme pembangkit listrik tenaga gelombang laut tipe pelampung silinder beberapa tahapan yang perlu disiapkan adalah, menyiapkan kolam pembuat gelombang buatan dan selanjutnya memasang mekanisme diatas permukaan air kolam. Prinsip dari model mekanisme ini adalah mengubah gerakan translasi ke rotasi yang selanjutnya diterima oleh generator. Pada tahap selanjutnya adalah penyiapan alat perekam data yaitu oscilloscope yang nantinya data tersebut diproses pada komputer. Rangkaian percobaan ditunjukkan pada Gambar 3.

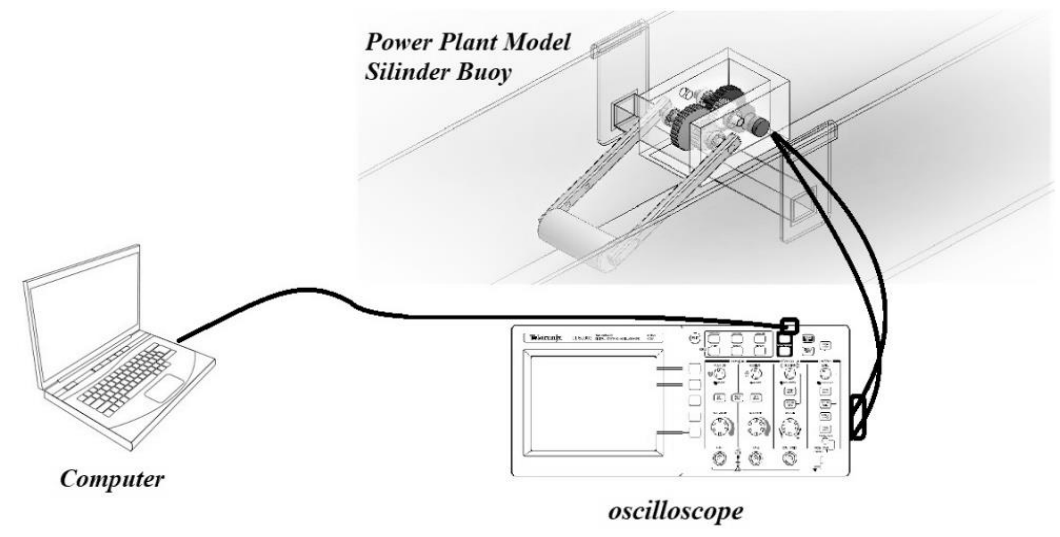

Gambar 3. Rangkaian Percobaan

Percobaan dilakukan dengan beberapa variasi yaitu, mengubah jarak pemberat yang terletak pada lengan ayun, dengan menggunakan jarak $7 \mathrm{~cm}, 15 \mathrm{~cm}$, dan $23 \mathrm{~cm}$, serta variasi pada generator yang memiliki diameter kawat yang berbeda - beda yaitu $0.2 \mathrm{~mm}, 0.3 \mathrm{~mm}$, dan $0.4 \mathrm{~mm}$. 
Hasil yang diperoleh pada pengujian adalah dalam bentuk watt. Skema mekanisme serta bagian dari mekanisme ditunjukkan pada Gambar 4.

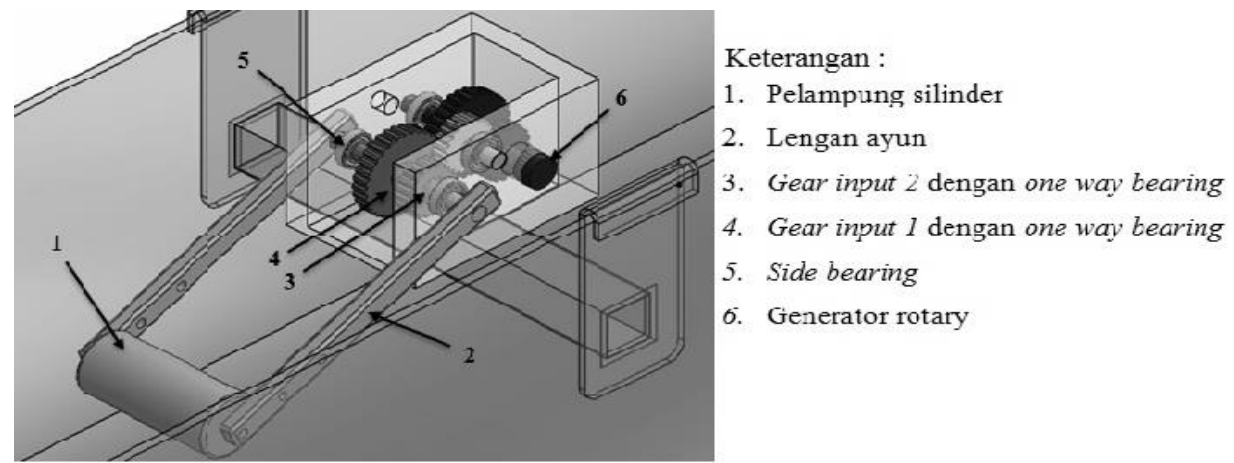

Gambar 4. Skema Mekanisme dan Bagian-bagiannya

Parameter yang digunakan pada mekanisme disesuaikan dengan parameter yang digunakan pada model penelitian sebelumnya dimana parameter ditunjukkan pada Tabel 1 dan 2 .

Tabel 1. Parameter Pada Gelombang

\begin{tabular}{llll}
\hline Simbol & Keterangan & Nilai & Satuan \\
\hline Hwave & Tinggi gelombang & 8.04 & $\mathrm{~cm}$ \\
Twave & Periode gelombang & 1 & $\mathrm{~s}$ \\
Fwave & Frek. Gelombang & 1 & $\mathrm{~Hz}$ \\
Awave & Amp. Gelombang & 4.02 & $\mathrm{~m}$ \\
P water & Masa jenis & 1000 & $\mathrm{~kg} / \mathrm{m}^{3}$ \\
& & & \\
g & Percepatan grafitasi & 9.81 & $\mathrm{~m} / \mathrm{s}^{2}$ \\
$\lambda$ wave & Panjang & 0.97 & $\mathrm{~cm}$ \\
& Gelombang & & \\
\hline
\end{tabular}

Tabel 2. Parameter Mekanisme

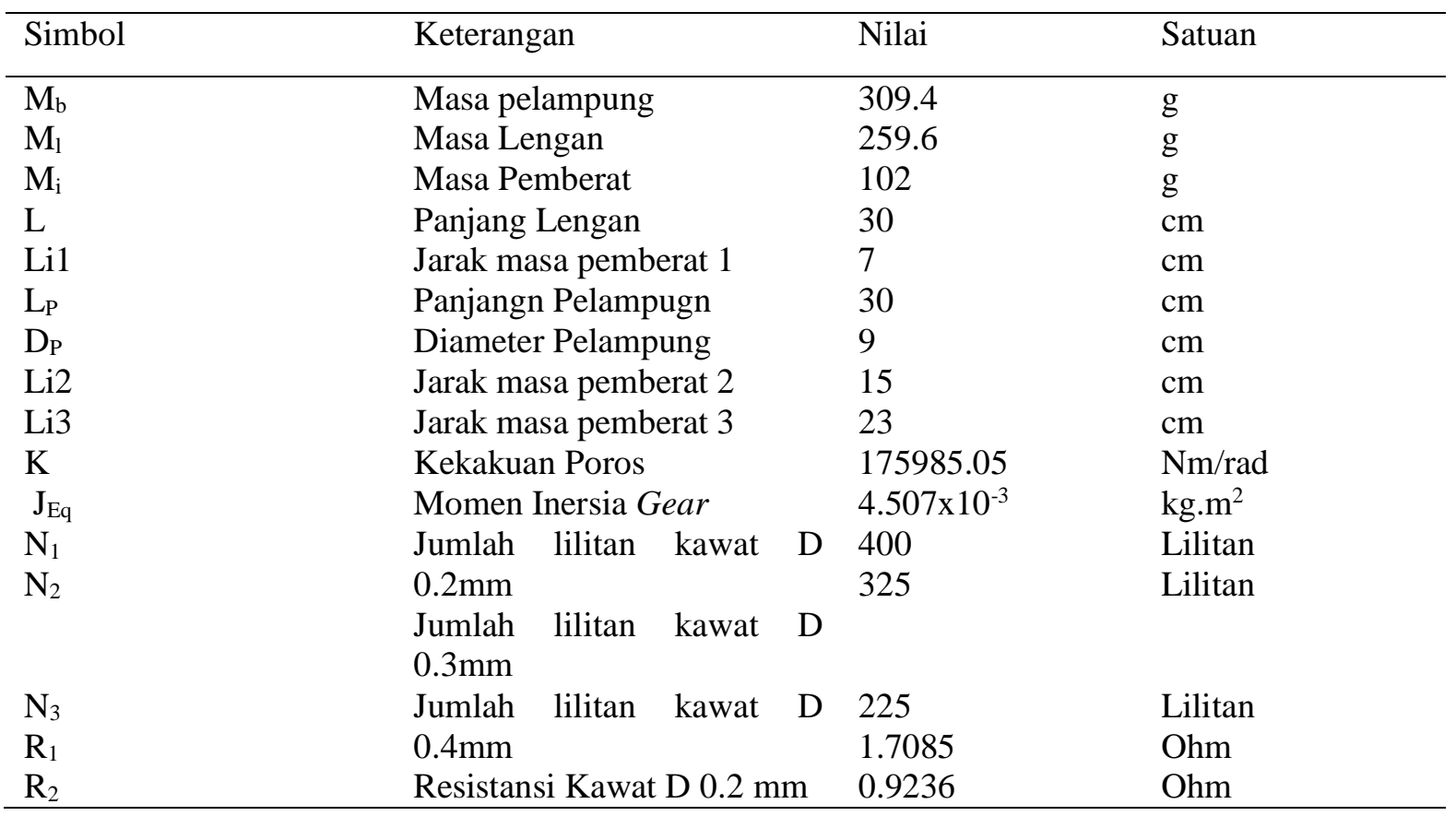




$\mathrm{R}_{3}$
$\mathrm{~L}_{\text {wirel }}$
$\mathrm{L}_{\text {wire2 }}$
$\mathrm{L}_{\text {wire3 }}$
$\mathrm{L}_{\text {ind1 }}$
$\mathrm{L}_{\text {ind3 }}$
$\rho_{\text {wire }}$
$\mathrm{L}_{\text {coil }}$
A
$\mathrm{B}$
$\mathrm{H}$
$\mu$

Resistansi Kawat D $0.3 \mathrm{~mm}$

Resistansi Kawat D $0.4 \mathrm{~mm}$

Panjang Kawat D $0.2 \mathrm{~mm}$

Panjang Kawat D $0.3 \mathrm{~mm}$

Panjang Kawat D $0.4 \mathrm{~mm}$

Induktansi kawat D $0.2 \mathrm{~mm}$

Induktansi kawat D $0.4 \mathrm{~mm}$

Resistivitas bahan tembaga

Panjang kumparan

Luas penampang kumparan

Kerapatan fluks magnet

Kuat medan magnet

Permeabilitas bahan

$\begin{array}{ll}0.4802 & \text { Ohm } \\ 20.1 & \mathrm{~m} \\ 16.3 & \mathrm{~m} \\ 11.3 & \mathrm{~m} \\ 20.1 & \mathrm{H} \\ 10.53 & \mathrm{H} \\ 1.7 \times 10^{-8} & \Omega \mathrm{m} \\ 0.03 & \mathrm{M} \\ 0.26 & \mathrm{~m}^{2} \\ 1.25 & \mathrm{Tesla} \\ 52000 & \mathrm{At} / \mathrm{m} \\ 24 \times 10^{-6} & \mathrm{Tm} / \mathrm{A} \mathrm{t}\end{array}$

0.4802

Ohm

$\mathrm{m}$

$\mathrm{H}$

$\Omega \mathrm{m}$

$\mathrm{M}$

Tesla

$\mathrm{Tm} / \mathrm{A} \mathrm{t}$

\section{HASIL DAN PEMBAHASAN}

Dari pengujian mekanisme alat pembangkit listrik tenaga gelombang laut tipe pelampung silinder menggunakan kolam simulator sebagai media pembuat gelombang laut dengan variasi diameter kawat pada generator $0.2 \mathrm{~mm}, 0.3 \mathrm{~mm}$, dan $0.4 \mathrm{~mm}$, serta variasi jarak pemberat pada lengan ayun pada jarak $7 \mathrm{~cm}$ didapat hasil yang ditunjukkan pada Gambar 5(a) dan 5(b).

Pada Gambar 3(a) hasil percobaan dengan variasi diameter kawat menggunakan jarak masa pemberat pada lengan ayun $7 \mathrm{~cm}$, daya bangkitan terbesar dalam $R M S$ volt ada pada generator dengan diameter kawat $0.4 \mathrm{~mm}$ yaitu sebesar 0.0494 volt. Sedangkan pada diameter kawat $0.2 \mathrm{~mm}$ sebesar $0.0256 \mathrm{~V}$ dan diameter kawat $0.3 \mathrm{~mm}$ sebesar $0.0336 \mathrm{~V}$.

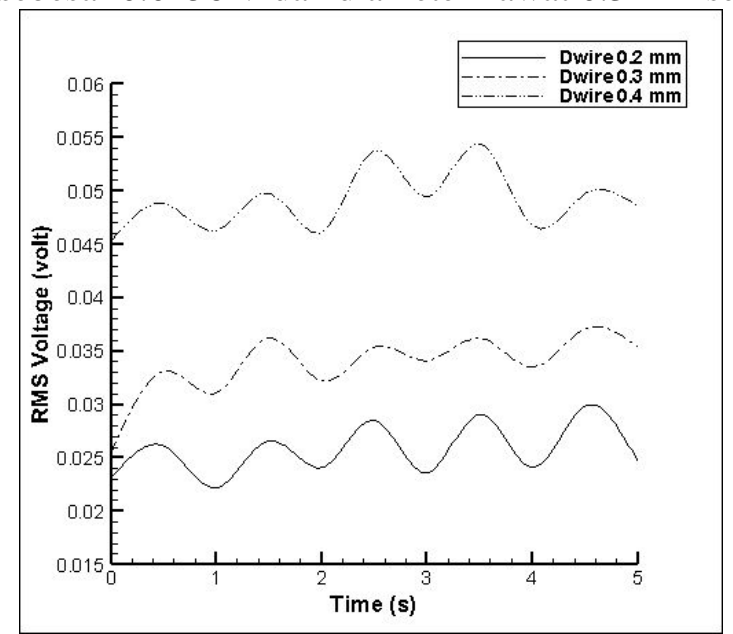

(a)

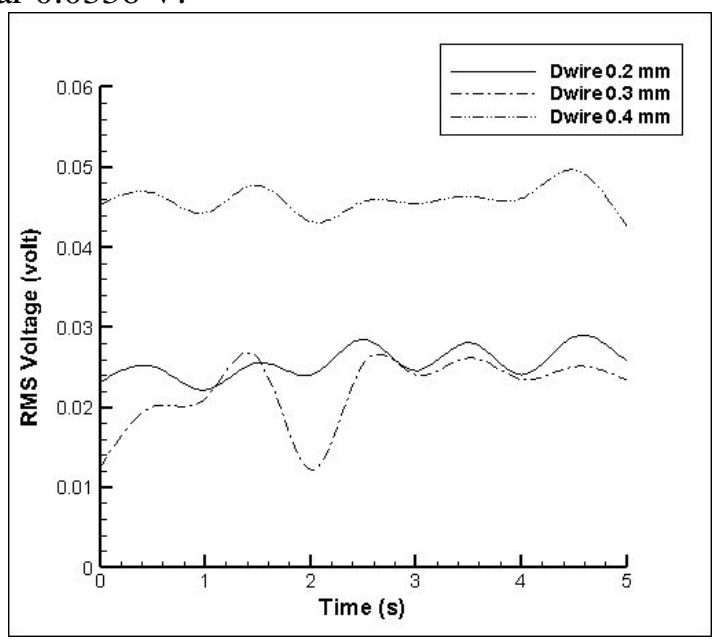

(b)

Gambar 5. (a) Grafik variasi diameter kawat pada jarak masa pemberat $7 \mathrm{~cm}$. (b) Grafik variasi diameter kawat pada jarak masa pemberat $15 \mathrm{~cm}$.

Hasil percobaan dengan variasi diameter kawat pada jarak masa pemberat $15 \mathrm{~cm}$ yang ditunjukkan pada gambar 5b. Nilai keluaran dalam RMS volt tertinggi adalah pada diameter kawat $0.4 \mathrm{~mm}$ yaitu sebesar $0.0451 \mathrm{~V}$ sedangkan nilai terendah pada diameter kawat $0.3 \mathrm{~mm}$ yaitu 0.0205 $\mathrm{V}$, dan pada diameter kawat $0.2 \mathrm{~mm}$ mendapat hasil sebesar $0.0254 \mathrm{~V}$.

Pada variasi diameter kawat dengan jarak masa pemberat $23 \mathrm{~cm}$ ditunjukkan pada gambar 6a, dimana nilai tertinggi juga pada diameter kawat $0.4 \mathrm{~mm}$ yaitu sebesar $0.0433 \mathrm{~V}$. sedangkan pada diameter kawat 0.2 ialah $0.0235 \mathrm{~V}$, dan pada diameter kawat $0.3 \mathrm{~mm}$ sebesar $0.0257 \mathrm{~V}$. 


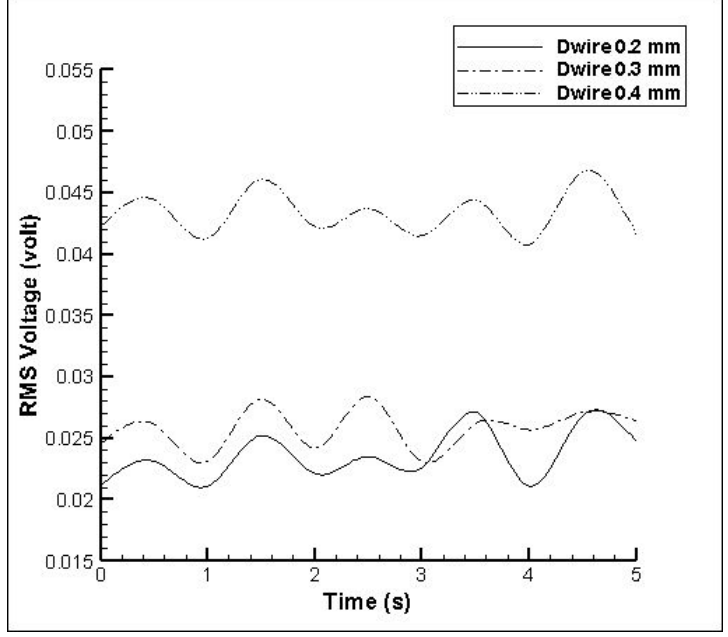

(a)

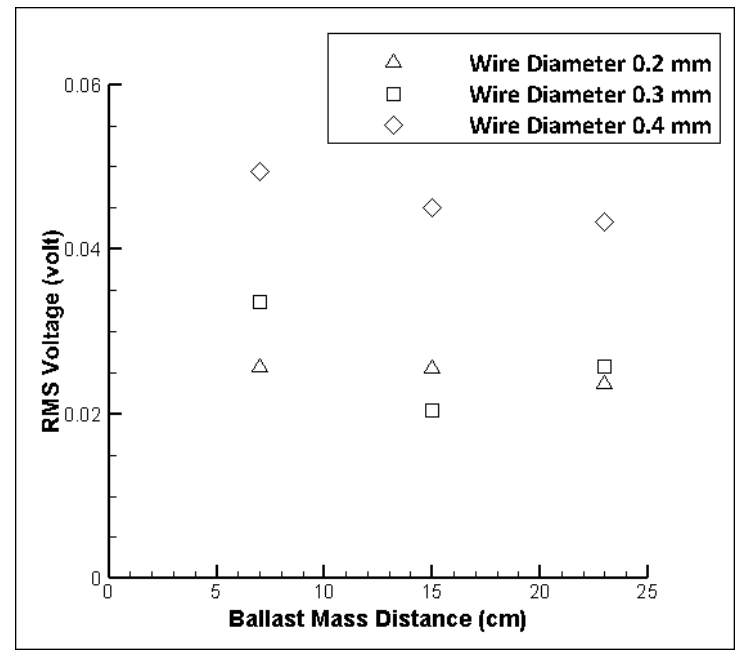

(b)

Gambar 6. (a) Grafik variasi diameter kawat pada jarak masa pemberat $23 \mathrm{~cm}$. (b) Hasil RMS volt variasi diameter kawat pada variasi jarak masa pemberat 7,15, dan $23 \mathrm{~cm}$.

Dari Gambar 6(b) dimana pada variasi diameter kawat nilai bangkitan terbesar ada pada generator dengan diameter kawat $0.4 \mathrm{~mm}$ dan terendah $0.2 \mathrm{~mm}$, sedangkan pada variasi jarak masa pemberat hasil terbesar ada pada jarak $7 \mathrm{~cm}$ dan terendah pada jarak $23 \mathrm{~cm}$. Hal ini dipengaruhi oleh perbedaan hambatan pada masing-masing generator dan perbedaan torsi yang terjadi pada masing-masing jarak pemberat. Hasil dari pengujian di tampilkan dalam bentuk keluaran RMS volt pada tiap variasi pada Tabel 3 .

Tabel 3. Hasil ekperimen

\begin{tabular}{ccc}
\hline Diameter Kawat (mm) & $\begin{array}{c}\text { Jarak Pemberat } \\
(\mathrm{cm})\end{array}$ & RMS (volt) \\
\hline 0.2 & 7 & 0.0256 \\
0.2 & 15 & 0.0254 \\
0.2 & 23 & 0.0235 \\
0.3 & 7 & 0.0336 \\
0.3 & 15 & 0.0205 \\
0.3 & 23 & 0.0257 \\
0.4 & 7 & 0.0494 \\
0.4 & 15 & 0.0451 \\
0.4 & 23 & 0.0433 \\
\hline
\end{tabular}

Perbandingan hasil simulasi dengan ekperimen ditunjukkan pada Gambar 7 di bawah ini.

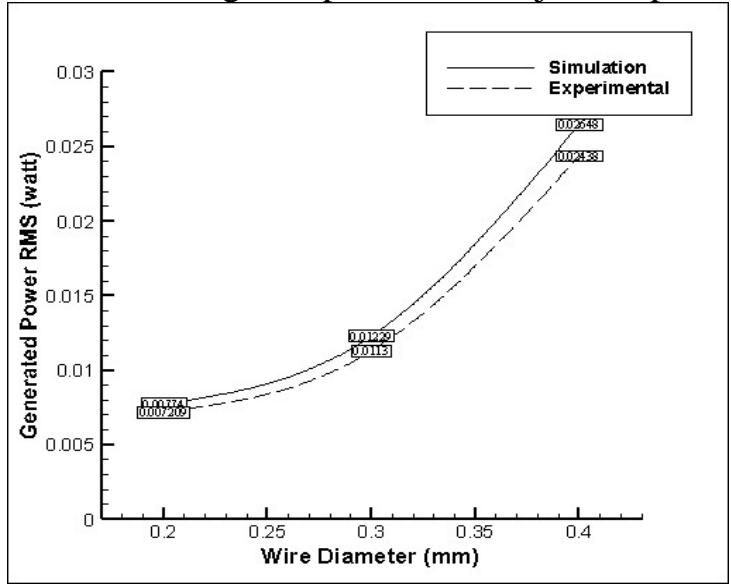

Gambar 7. Grafik perbandingan hasil simulasi dengan ekperimen dalam RMS(watt) 
Pada Gambar 7 adalah grafik perbandingan hasil simulasi dengan eksperimen dimana data simulasi didapat dari penelitian terdahulu [9], daya yang dihasilkan oleh model simulasi (watt) memiliki tren yang sama dengan hasil eksperimen sekarang, dengan hasil tertinggi dimiliki oleh hasil simulasi namun tidak terlalu jauh berbeda dengan hasil ekperimen yang memiliki hasil dibawahnya. Perbedaan hasil simulasi dengan eksperimen dibuat dalam persentase nilai error, dimana error yang didapat sebesar 8,238 \%. Hal ini dikarenakan pada model simulasi tidak memiliki adanya losses atau rugi-rugi akibat adanya gangguan eksternal seperti yang dimiliki oleh mekanisme maupun sistem pada saat pengujian. Dengan didapatkannya daya terbesar pada skala laboratorium yaitu sebesar 0.02438 watt dan inputan daya yang di gunakan sebesar 0.9018 watt maka effisiensi sistem didapatkan sebagai berikut.

$$
\eta=\frac{P_{\text {out }}}{P_{\text {in }}} x 100 \% \quad \text {....(1) } \quad \text { efisiensi mekanis } \frac{0.02438}{0.9018}=2,7 \%
$$

\section{KESIMPULAN}

Dari eksperimen yang dilakukan didapatkan hasil yaitu, pada variasi jarak masa pemberat hasil terbaik didapat pada masa jarak $7 \mathrm{~cm}$ namun perbedaan hasil tidak terlalu signifikan, dikarenakan jarak yang digunakan tidak terlalu jauh. Pada variasi diameter kawat hasil terbaik di miliki oleh generator dengan diameter kawat $0.4 \mathrm{~mm}$, yaitu sebesar $0.02438 \mathrm{~W}$. Efisiensi sistem berdasarkan data dari parameter dan hasil yang diperoleh adalah $2.7 \%$. Dari perbandingan hasil yang didapat, pengujian yang dilakukan memiliki hasil yang sesuai dengan model simulasi sebelumnya namun nilainya lebih rendah dikarenakan adanya rugi - rugi mekanis yang terjadi pada model mekanisme pembangkit listrik tenaga gelombang laut.

\section{DAFTAR PUSTAKA}

[1] R. Alamian, R. Shafaghat, S. J. Miri, and N. Yazdanshenas, "Evaluation of technologies for harvesting wave energy in Caspian Sea," Renew. Sustain. Energy Rev., vol. 32, pp. 468-476, 2014.

[2] A. Wahyudie, M. A. Jama, O. Saeed, H. Noura, A. Assi, and K. Harib, "Robust and low computational cost controller for improving captured power in heaving wave energy converters," Renew. Energy, pp. 1-11, 2014.

[3] S. Brusca, F. Cucinotta, A. Galvagno, R. Lanzafame, S. Mauro, and M. Messina, "Oscillating Water Column Wave Energy Converter by Means of Straight-bladed Darrieus Turbine," Energy Procedia, vol. 82, pp. 766-773, Dec. 2015.

[4] S. Brusca, A. Galvagno, R. Lanzafame, A. M. Cugno Garrano, S. Mauro, and M. Messina, "On the turbine-induced damping in Oscillating Water Column wave energy converter," Energy Procedia, vol. 126, pp. 581-588, 2017.

[5] M. P. Kazmierkowski and M. Jasi, "Power Electronics for Renewable Sea Wave Energy," pp. 4-9, 2010.

[6] X. Niu, "Modeling and Design Analysis of a Permanent Magnet Linear Synchronous Generator," pp. 1-47, 2013.

[7] P. M. C. Godinho, M. R. A. Calado, and S. J. P. S. Mariano, "Design and numerical analysis of a new linear generator for wave energy conversion," pp. 525-529, 2011.

[8] R. Vandana, "Design Methodology for High-Performance Segmented Rotor Switched Reluctance Motors," vol. 30, no. 1, pp. 11-21, 2015.

[9] M. Ulum, "Analysis on Electrical Energy from Cylindrical-Buoy-Type Sea Wave Power Plant Model," in Analysis on Electrical Energy from Cylindrical-Buoy-Type Sea Wave Power Plant Model, 2017, pp. 1-4.

[10] M. E. McCormick, Ocean Engineering Mechanics. New York: United States of America by Cambridge University Press, New York. 


\section{Halaman ini sengaja dikosongkan}

